\title{
Violence among Students with and without Special Needs in Regular Education
}

\author{
Nirit Karni Vizer \\ Department of Special Education, University of Haifa, Haifa, Israel \\ Email: niritkarni2@gmail.com
}

Received 13 August 2015; accepted 14 September 2015; published 18 September 2015

\begin{abstract}
The current study focuses on students with special needs who are integrated in mainstream education frameworks. The first aim of the study is to determine whether students with and without special needs exhibit different levels of violence. The second aim is to determine the impact of a specially-designed intervention program which is implemented with students with special needs and intends to increase their understanding of the various aspects of violence. The current study involved 561 (197 of them with special needs) male and female students studying in the $7^{\text {th }} 9^{\text {th }}$ grade in an regional junior high school in Israel. All the students completed the "Bully/Victim Questionnaire" [1]. Students with special needs participated in an intervention program based on the Cycle of Internalized Learning (CIL) model [2]. After completing the intervention program, students' perceptions of violence were reassessed by using the "Bully/Victim Questionnaire". The pre-intervention findings indicated no difference in the pattern or the level of violence among students with special needs and the other students at the school, where as post-intervention. Findings revealed that students with special needs expressed higher incidences of violence than their peers who had not participated in the intervention.
\end{abstract}

\section{Keywords}

Violence, Students with Special Needs, Intervention Program

\section{Introduction}

A Post from Facebook (6/7/2015): "The smiling boy in the picture was supposed to celebrate his $20^{\text {th }}$ birthday this week. He will not celebrate it anymore! He was a happy boy, who grew up in a loving home, like all of us, a beloved son and brother. He went to school every morning, like all of us, waving goodbye to his parents, with a smile for another day at school. But every school day was a torture for him. He considered his classmates to be his friends, but they saw him as a playing object. They humiliated and brutalized him during recess. Why? Because he was short. After he came home from school, to his safe haven, he logged on to his Facebook. But those 'friends' were there too, continuing to harass, humiliate, abuse, and shun him. He did not share this with his mother so as not to upset her or bother her. He had nowhere to run, so he committed suicide. He will never fall in love, never experience heartbreak, will never go to university, will never marry, will never see his children 
play, and will never celebrate 20...”

In recent years, there has been a dramatic increase in reported violence rates among school students [3]-[8]. The current study compared violence among students with special needs (learning disabilities, behavioral problems, IDD, ADHD, etc.) who were integrated in the mainstream educational frameworks, and violence among students without special needs.

Violence can take the form of a physical, verbal or emotional offense, or it can have a more pervasive effect in the form of an aggressive relationship. Violence can be aimed towards the victim directly or indirectly, through rumors and gossip to which students are exposed. In addition, research findings have revealed that in general, boys are victims of violence more often than girls. The consequences of violent behavior influence the school's environment, have an effect on the personal welfare of students and cause feelings of unsafety around school [3] [7]-[10].

According to Mitchell [11], students with special needs constitute 10 - 15 percent of the regular school population. They experience academic difficulties learning; some have motor impairments; others encounter difficulties in social adjustments. Furthermore, studies indicate that integrated students with special needs are the target of violence [3]-[5] [12] more frequently than students without special needs [13]-[15].

The area of inclusion has been studied from different aspects [16]-[19], but no investigation to date has examined the integrated child's point of view about violence, either as a target or as the inflictor of violence. Therefore, the first aim of the present study was to find out whether differences exist in the pattern and/or level of violence exhibited by students with and without special needs. The second aim was to examine the impact of a specially-designed intervention program implemented with students with special needs to raise their awareness of violent behavior.

\section{Method}

Participants: The current study involved 561 students (197 with special needs, 364 without special needs) studying in $7^{\text {th }}-9^{\text {th }}$ grades in a junior high school in Israel.

Tools: To get information about the patterns and the level of violence, all of the participants completed the "Bully/Victim Questionnaire" [1]. The grades were scored on a Likert-like scale, whereby $1=$ Never and $4=$ Always. The questionnaire included 27 items that deal with violence, for example, "How often have you been threatened at school?" and "Has anybody ever cursed at you at school?". The reliability of the questionnaire was Cronbach's $\alpha=0.836$.

Students with special needs participated in an intervention program based on the Cycle of Internalized Learning (CIL) model [2]. The stages of the CIL model are:

1. Presentation-A specific topic is presented and considered in reference to real-life experiences. Topic selection is based on the learners' worlds and needs and on the school curriculum or other formal needs. Their response is subjective and concrete, expressing an initial, personal awareness.

2. Teaching-Academic teaching, including an analysis of the topic under study, and a clarification of definitions and generalizations. The various components of the subject matter are identified and defined in relation to the participants' experiences. School skills and cultural norms are also learned during this stage.

3. Discussion-Learners are encouraged to raise personal responses, to relate to themselves and others in a critical manner, according to concepts and skills learned in Stage 2. Based on the personal input of the learners and the concepts learned, learners suggested alternative or new ways to behaving and problem solving.

4. Review - The group uses role playing, simulations, or practical outdoor activities to experience the alternative ways of behavior suggested by them. This stage affords a review of the subjects learned, while incorporating the changes and solutions proposed by the group members.

5. Conclusions \& Learning-A follow-up group discussion is conducted to learn lessons from reviewing the subject. Learners are encouraged to form an autonomous perspective and a cohesive set of priorities. The focus is on values that underline individual and group behavior, and to consider what participants learn about themselves and others.

The CIL model was modified for the purpose of the present study.

Procedure: In the first stage of the study, the "Bully/Victim Questionnaire” was administered to the experimental and comparison groups. In the second stage, the group intervention program was implemented. The program included ten sessions, each of which lasted an hour and a half (2 lessons), and focused on raising aware- 
ness to violence. A quantity analysis of the processes that occurred during the intervention program was conducted. The purpose of the first and the second sessions of the intervention program was to draw a distinction between physical violence and verbal violence, and to learn about each type of violence. In the third and the fourth sessions the concept of verbal violence was discussed. The fifth and the sixth sessions focused on bullying. The seventh and eighth sessions dealt with harassment, and the last two sessions focused on teasing, and a summary of the intervention program.

In the third stage, at the end of the intervention program, the "Bully/Victim Questionnaire" was completed once again by both the experimental and the comparison group.

\section{Findings}

The first aim of the study was to compare the patterns of violence found among adolescents with and without special needs. Mann Whitney U test was used to identify differences between the violent behavior of adolescents with and without special needs. The analysis provided mostly non-significant results: $Z=0.02$ to $Z=1.92$ ( $p$ > 0.05). Only on one variable-that of theft-were differences found. On the remaining variables, i.e., curse, kicking, humiliation, name-calling, beating, boycotting, insulting, threating, pushing, no differences existed. Only the factor of theft in the previous month, was significant $(Z=2.31, p=0.021)$. Results showed that $12.9 \%$ of the adolescents in the comparison group reported to have been victims of theft, compared to $20.9 \%$ adolescents in the research group. This finding indicated that students with special needs were more susceptible to theft.

Regarding levels of violence, the findings indicated no differences between students with special needs and students without special needs. The mean scores obtained by the experimental and comparison groups before the intervention program, are presented in Table 1, organized by group and gender $(\mathrm{N}=561)$.

Based on the data in Table 1, it appears that there is no initial difference in the level of violence among students with special needs and students without special needs. On the measures of indirect bullying, victim of injury, and victim of general violence, verbal violence, and physical violence, no differences were found between the groups. The only difference between the experimental and comparison groups was related to gender. As victims of violence, the boys' mean score was significantly higher $(p<0.001)$ than that of the girls.

The second aim of the study was to determine the impact of a specially-designed intervention program implemented with students with special needs to improve their understanding of the different aspects of violence. Findings based on the re-administration of the "Bully/Victim Questionnaire" revealed that the intervention program increased the level of consciousness of the participants regarding their violent behavior, as shown in Table 2.

Data in Table 2 indicate an increase in the reporting of violence among students with special needs, i.e., among members of the experimental group who participated in the intervention program, both as victims of general violence and as attackers, and there was no significant change in the comparison group.

\section{Discussion}

The current research focuses on the phenomenon of violence that occurs among students with and without special needs in a mainstream junior high school. During the 1990s, when the policy of integration was implemented worldwide, the phenomenon of violence in schools became a critical issue for students with special needs. Research showed that students with special needs who were integrated in mainstream schools were exposed to more violence than students without special needs [12] [20] [21].

It is important to note that though there are ample studies about violence against adults and children with special needs in general [6] [22]-[24], there are only a few studies on violence against students with special needs that are integrated in mainstream schools [12] [20] [21].

In the present study, a comparison was conducted between integrated students with special needs and students without special needs, in terms of the pattern and the level of violence. This was examined using the "Bully/ Victim Questionnaire". The findings of the present study revealed that there was no difference between the patterns of violence found among students with special needs compared to those found among students without special needs, apart from a higher level of theft concerning students with special needs. However, there was a greater tendency towards violence among boys compared to girls in both groups.

Following the first administration of the "Bully/Victim Questionnaire", an intervention program was implemented with students with special needs. At the end of the program, the "Bully/Victim Questionnaire" was readministered to the experimental and comparison groups. Findings showed a rise in students' awareness to incidents 
Table 1. Average, standard deviation and analysis of variance to examine the differences in the patterns of violence by group and gender $(\mathrm{N}=561)$.

\begin{tabular}{|c|c|c|c|c|c|c|c|c|c|c|c|c|}
\hline & \multicolumn{3}{|c|}{$\begin{array}{l}\text { Experimental Group } \\
\qquad(\mathrm{N}=197)\end{array}$} & \multicolumn{3}{|c|}{$\begin{array}{l}\text { Comparison group } \\
\qquad(\mathrm{N}=364)\end{array}$} & \multicolumn{3}{|c|}{$\begin{array}{c}\text { Total } \\
(\mathrm{N}=561)\end{array}$} & \multirow{2}{*}{$\begin{array}{c}\text { Group } \\
\text { F } \\
(1557) \\
\left(\eta^{2}\right)\end{array}$} & \multirow{2}{*}{$\begin{array}{c}\text { Gander } \\
\text { F } \\
(1557) \\
\left(\eta^{2}\right)\end{array}$} & \multirow{2}{*}{$\begin{array}{c}\begin{array}{c}\text { Group X } \\
\text { Gander }\end{array} \\
\text { F } \\
\left(\begin{array}{c}1557) \\
\left(\eta^{2}\right)\end{array}\right.\end{array}$} \\
\hline & $\begin{array}{c}\text { Boys } \\
\text { M } \\
(\mathrm{SD}) \\
(\mathrm{n}=96)\end{array}$ & $\begin{array}{c}\text { Girls } \\
\text { M } \\
(\mathrm{SD}) \\
(\mathrm{n}=101)\end{array}$ & $\begin{array}{c}\text { Total } \\
\text { M } \\
(\mathrm{SD}) \\
(\mathrm{n}=197)\end{array}$ & $\begin{array}{c}\text { Boys } \\
\text { M } \\
(\mathrm{SD}) \\
(\mathrm{n}=172)\end{array}$ & $\begin{array}{c}\text { Girls } \\
\text { M } \\
(\mathrm{SD}) \\
(\mathrm{n}=192)\end{array}$ & $\begin{array}{c}\text { Total } \\
\text { M } \\
(\mathrm{SD}) \\
(\mathrm{n}=364)\end{array}$ & $\begin{array}{c}\text { Boys } \\
\text { M } \\
(\mathrm{SD}) \\
(\mathrm{n}=268)\end{array}$ & $\begin{array}{c}\text { Girls } \\
\text { M } \\
(\mathrm{SD}) \\
(\mathrm{n}=293)\end{array}$ & $\begin{array}{c}\text { Total } \\
\text { M } \\
(\mathrm{SD}) \\
(\mathrm{n}=561)\end{array}$ & & & \\
\hline $\begin{array}{l}\text { Sense of indirect } \\
\text { bullying }\end{array}$ & $\begin{array}{l}1.55 \\
(0.58)\end{array}$ & $\begin{array}{l}1.51 \\
(0.49)\end{array}$ & $\begin{array}{l}1.52 \\
(0.54)\end{array}$ & $\begin{array}{l}1.47 \\
(0.48)\end{array}$ & $\begin{array}{l}1.52 \\
(0.47)\end{array}$ & $\begin{array}{l}1.50 \\
(0.47)\end{array}$ & $\begin{array}{l}1.50 \\
(0.52)\end{array}$ & $\begin{array}{l}1.52 \\
(0.48)\end{array}$ & $\begin{array}{c}1.51 \\
(0.50)\end{array}$ & $\begin{array}{c}0.40 \\
(0.001)\end{array}$ & $\begin{array}{c}0.03 \\
(0.001)\end{array}$ & $\begin{array}{c}1.12 \\
(0.002)\end{array}$ \\
\hline Injury victim & $\begin{array}{l}1.35 \\
(0.51)\end{array}$ & $\begin{array}{l}1.27 \\
(0.46)\end{array}$ & $\begin{array}{l}1.31 \\
(0.48)\end{array}$ & $\begin{array}{l}1.32 \\
(0.56)\end{array}$ & $\begin{array}{l}1.27 \\
(0.41)\end{array}$ & $\begin{array}{l}1.29 \\
(0.49)\end{array}$ & $\begin{array}{l}1.33 \\
(0.54)\end{array}$ & $\begin{array}{l}1.27 \\
(0.43)\end{array}$ & $\begin{array}{l}1.30 \\
(0.49)\end{array}$ & $\begin{array}{c}0.11 \\
(0.001)\end{array}$ & $\begin{array}{c}2.08 \\
(0.004)\end{array}$ & $\begin{array}{c}0.08 \\
(0.001)\end{array}$ \\
\hline $\begin{array}{l}\text { Victim-General } \\
\text { violence }\end{array}$ & $\begin{array}{l}1.28 \\
(0.45)\end{array}$ & $\begin{array}{l}1.24 \\
(0.47)\end{array}$ & $\begin{array}{l}1.26 \\
(0.46)\end{array}$ & $\begin{array}{l}1.28 \\
(0.53)\end{array}$ & $\begin{array}{l}1.20 \\
(0.35)\end{array}$ & $\begin{array}{l}1.24 \\
(0.45)\end{array}$ & $\begin{array}{l}1.28 \\
(0.50)\end{array}$ & $\begin{array}{l}1.22 \\
(0.40)\end{array}$ & $\begin{array}{l}1.25 \\
(0.45)\end{array}$ & $\begin{array}{c}0.31 \\
(0.001)\end{array}$ & $\begin{array}{c}1.75 \\
(0.003)\end{array}$ & $\begin{array}{c}0.23 \\
(0.001)\end{array}$ \\
\hline $\begin{array}{l}\text { Victim-Verbal } \\
\text { violence }\end{array}$ & $\begin{array}{l}1.59 \\
(0.88)\end{array}$ & $\begin{array}{c}1.44 \\
(0.69)\end{array}$ & $\begin{array}{l}1.51 \\
(0.79)\end{array}$ & $\begin{array}{l}1.52 \\
(0.80)\end{array}$ & $\begin{array}{c}1.52 \\
(0.73)\end{array}$ & $\begin{array}{l}1.52 \\
(0.76)\end{array}$ & $\begin{array}{l}1.55 \\
(0.83)\end{array}$ & $\begin{array}{l}1.49 \\
(0.72)\end{array}$ & $\begin{array}{l}1.52 \\
(0.77)\end{array}$ & $\begin{array}{c}0.01 \\
(0.001)\end{array}$ & $\begin{array}{c}1.35 \\
(0.002)\end{array}$ & $\begin{array}{c}1.16 \\
(0.002)\end{array}$ \\
\hline $\begin{array}{l}\text { Victim-Physical } \\
\text { violence }\end{array}$ & $\begin{array}{l}1.27 \\
(0.54)\end{array}$ & $\begin{array}{l}1.19 \\
(0.44)\end{array}$ & $\begin{array}{l}1.23 \\
(0.49)\end{array}$ & $\begin{array}{c}1.24 \\
(0.62)\end{array}$ & $\begin{array}{l}1.19 \\
(0.47)\end{array}$ & $\begin{array}{c}1.21 \\
(0.55)\end{array}$ & $\begin{array}{c}1.25 \\
(0.59)\end{array}$ & $\begin{array}{l}1.19 \\
(0.46)\end{array}$ & $\begin{array}{c}1.22 \\
(0.53)\end{array}$ & $\begin{array}{c}0.17 \\
(0.001)\end{array}$ & $\begin{array}{c}1.94 \\
(0.003)\end{array}$ & $\begin{array}{c}0.08 \\
(0.001)\end{array}$ \\
\hline Attacker & $\begin{array}{c}1.38 \\
(0.62)\end{array}$ & $\begin{array}{c}1.16 \\
(0.32)\end{array}$ & $\begin{array}{c}1.27 \\
(0.50)\end{array}$ & $\begin{array}{c}1.44 \\
(0.80)\end{array}$ & $\begin{array}{c}1.14 \\
(0.45)\end{array}$ & $\begin{array}{c}1.28 \\
(0.65)\end{array}$ & $\begin{array}{c}1.42 \\
(0.74)\end{array}$ & $\begin{array}{c}1.15 \\
(0.41)\end{array}$ & $\begin{array}{c}1.28 \\
(0.60)\end{array}$ & $\begin{array}{c}0.13 \\
(0.001)\end{array}$ & $\begin{array}{c}24.67^{* * *} \\
(0.042)\end{array}$ & $\begin{array}{c}0.59 \\
(0.001)\end{array}$ \\
\hline
\end{tabular}

${ }^{*} \mathrm{p}<0.05,{ }^{* *} \mathrm{p}<0.01,{ }^{* * *} \mathrm{p}<0.001$.

Table 2. Average, standard deviations, and analysis of variance for repeated measurements to examine the differences in the patterns of violence by group and time $(\mathrm{N}=470)$.

\begin{tabular}{|c|c|c|c|c|c|c|c|c|c|}
\hline & \multicolumn{2}{|c|}{$\begin{array}{l}\text { Experimental Group } \\
\qquad(\mathrm{N}=142)\end{array}$} & \multicolumn{2}{|c|}{$\begin{array}{l}\text { Comparison Group } \\
\qquad(\mathrm{N}=328)\end{array}$} & \multicolumn{2}{|c|}{$\begin{array}{c}\text { Total } \\
(\mathrm{N}=470)\end{array}$} & \multirow{2}{*}{$\begin{array}{c}\text { Group } \\
\text { F } \\
(1468) \\
\left(\eta^{2}\right)\end{array}$} & \multirow{2}{*}{$\begin{array}{c}\text { Time } \\
\text { F } \\
(1468) \\
\left(\eta^{2}\right)\end{array}$} & \multirow{2}{*}{$\begin{array}{c}\text { Group X Time } \\
\text { F } \\
(1468) \\
\left(\eta^{2}\right)\end{array}$} \\
\hline & $\begin{array}{c}\text { Before } \\
\text { M } \\
\text { (SD) }\end{array}$ & $\begin{array}{l}\text { After } \\
\text { M } \\
\text { (SD) }\end{array}$ & $\begin{array}{c}\text { Before } \\
\text { M } \\
\text { (SD) }\end{array}$ & $\begin{array}{l}\text { After } \\
\text { M } \\
\text { (SD) }\end{array}$ & $\begin{array}{c}\text { Before } \\
\text { M } \\
\text { (SD) }\end{array}$ & $\begin{array}{c}\text { After } \\
\text { M } \\
\text { (SD) }\end{array}$ & & & \\
\hline $\begin{array}{l}\text { Sense of indirect } \\
\text { bullying }\end{array}$ & $\begin{array}{l}1.48 \\
(0.46)\end{array}$ & $\begin{array}{c}1.59 \\
(0.69)\end{array}$ & $\begin{array}{l}1.50 \\
(0.44)\end{array}$ & $\begin{array}{l}1.54 \\
(0.51)\end{array}$ & $\begin{array}{l}1.49 \\
(0.44)\end{array}$ & $\begin{array}{c}1.55 \\
(0.57)\end{array}$ & $\begin{array}{c}0.26 \\
(0.001)\end{array}$ & $\begin{array}{c}5.33 \\
(0.011)\end{array}$ & $\begin{array}{c}0.94 \\
(0.002)\end{array}$ \\
\hline Injury victim & $\begin{array}{c}1.28 \\
(0.40)\end{array}$ & $\begin{array}{c}1.46 \\
(0.76)\end{array}$ & $\begin{array}{l}1.30 \\
(0.48)\end{array}$ & $\begin{array}{c}1.27 \\
(0.51)\end{array}$ & $\begin{array}{l}1.30 \\
(0.46)\end{array}$ & $\begin{array}{c}1.33 \\
(0.60)\end{array}$ & $\begin{array}{c}3.68 \\
(0.008)\end{array}$ & $\begin{array}{l}5.01^{*} \\
(0.011)\end{array}$ & $\begin{array}{l}10.50^{* *} \\
(0.022)\end{array}$ \\
\hline $\begin{array}{l}\text { victim-General } \\
\text { violence }\end{array}$ & $\begin{array}{c}1.22 \\
(0.34)\end{array}$ & $\begin{array}{c}1.38 \\
(0.72)\end{array}$ & $\begin{array}{c}1.25 \\
(0.44)\end{array}$ & $\begin{array}{c}1.18 \\
(0.37)\end{array}$ & $\begin{array}{c}1.24 \\
(0.41)\end{array}$ & $\begin{array}{c}1.24 \\
(0.51)\end{array}$ & $\begin{array}{c}5.48^{*} \\
(0.012)\end{array}$ & $\begin{array}{c}2.83 \\
(0.006)\end{array}$ & $\begin{array}{l}14.74^{* * *} \\
(0.031)\end{array}$ \\
\hline $\begin{array}{l}\text { Victim-Verbal } \\
\text { violence }\end{array}$ & $\begin{array}{c}1.44 \\
(0.67)\end{array}$ & $\begin{array}{c}1.76 \\
(0.99)\end{array}$ & $\begin{array}{c}1.54 \\
(0.77)\end{array}$ & $\begin{array}{c}1.46 \\
(0.70)\end{array}$ & $\begin{array}{c}1.51 \\
(0.74)\end{array}$ & $\begin{array}{c}1.55 \\
(0.81)\end{array}$ & $\begin{array}{c}2.56 \\
(0.006)\end{array}$ & $\begin{array}{c}6.61^{*} \\
(0.014)\end{array}$ & $\begin{array}{l}17.99^{* * *} \\
(0.037)\end{array}$ \\
\hline $\begin{array}{l}\text { Victim-Physical } \\
\text { violence }\end{array}$ & $\begin{array}{l}1.22 \\
(0.45)\end{array}$ & $\begin{array}{c}1.34 \\
(0.81)\end{array}$ & $\begin{array}{c}1.22 \\
(0.55)\end{array}$ & $\begin{array}{l}1.17 \\
(0.46)\end{array}$ & $\begin{array}{c}1.22 \\
(0.52)\end{array}$ & $\begin{array}{c}1.22 \\
(0.59)\end{array}$ & $\begin{array}{l}3.60 \\
(0.008)\end{array}$ & $\begin{array}{l}1.16 \\
(0.002)\end{array}$ & $\begin{array}{l}7.02^{* *} \\
(0.015)\end{array}$ \\
\hline Attacker & $\begin{array}{c}1.27 \\
(0.53)\end{array}$ & $\begin{array}{c}1.44 \\
(0.87)\end{array}$ & $\begin{array}{c}1.28 \\
(0.64)\end{array}$ & $\begin{array}{c}1.23 \\
(0.56)\end{array}$ & $\begin{array}{c}1.28 \\
(0.61)\end{array}$ & $\begin{array}{l}1.29 \\
(0.67)\end{array}$ & $\begin{array}{c}4.04^{*} \\
(0.009)\end{array}$ & $\begin{array}{c}2.18 \\
(0.005)\end{array}$ & $\begin{array}{l}7.38^{* *} \\
(0.016)\end{array}$ \\
\hline
\end{tabular}

${ }^{*} \mathrm{p}<0.05,{ }^{* *} \mathrm{p}<0.01,{ }^{* * *} \mathrm{p}<0.001$.

of violence. Furthermore, following the program, they had more confidence in being outspoken about violence against and among them.

The highly significant differences that were found between the experimental and the comparison groups following the intervention are in line with findings of other studies, which demonstrate that students with special needs are more susceptible to violence in school. During the intervention program, the students gained insight into everyday situations of violence against them and among them. The CIL-based intervention program was found to be effective in raising participants' awareness of violent behavior. This finding is similar to findings of other programs that deal with violence and are based on group discussion and dialogue among students [7] [8].

Reiter's [2] ecological model claims that people with special needs have low self-esteem; they grow up with deficits in social skills due to negative social experiences. All of the above can be changed by running intervention programs in social education, aimed to strengthen individuals with disabilities, by enhancing their ability to 
demonstrate self-determination in the context of social harassment.

\section{Limitations}

The researcher approached several school principals requesting permission to conduct the research among their students. However, only one principal agreed to conduct the research in her school; the others were reluctant to address the issue of violence. Another limitation may be the short period of the intervention program. A longer program might lead to a behavioral and perceptional change among all participating students.

\section{References}

[1] Olweus, D. (1991) Bully/Victim Problems among Schoolchildren: Basic Facts and Effects of a School Based Intervention Program. In: Pepler, D.J. and Rubin, K.H., Eds., The Development and Treatment of Childhood Aggression Hillsdale, Lawrence Erlbaum, NJ, 411-448.

[2] Reiter, S. (2008) Disability from a Humanistic Perspective: Towards a Better Quality of Life. Book Series: Health and Human Development, Nova Science Publishers, New York.

[3] Balin-Arcaro, C., Smith, J.D., Cunningham, C.E., Vaillancourt, T.and Rimas, H. (2012) Contextual Attributes of Indirect Bullying Situations that Influence Teachers’ Decisions to Intervene. Journal of School Violence, 11, 226-245. http://dx.doi.org/10.1080/15388220.2012.682003

[4] Evans, P. (2010) The Verbally Abusive Relationship: How to Recognize It and to Respond. Adams Media, Avon.

[5] Evans, P. (2012) Victory over Verbal Abuse: A Healing Guide to Renewing Your Spirit and Reclaiming Your Life. Adams Media, Avon.

[6] Karni-Vizer, N. (2014) Effectiveness of an Intervention on Verbal Violence among Students with Intellectual Disabilities. International Journal of Secondary Education, 3, 1-7.

[7] Lund, M., Blake, J.J., Ewing, H.K. and Banks, C.S. (2012) School Counselors’ and School Psychologists’ Bullying Prevention and Intervention Strategies: A Look into Real-World Practices. Journal of School Violence, 11, 246-265. http://dx.doi.org/10.1080/15388220.2012.682005

[8] Sherer, Y.C. and Nickerson, A. B. (2010) Anti-Bullying Practices in American Schools: Perspectives of School Psychologists. Psychology in the Schools, 47, 217-229. http://dx.doi.org/10.1002/pits.20466

[9] Bernes, B.K. and Bardick D.A. (2007) Conducting Adolescent Violence Risk Assessment: A Framework for School Counselors. Professional School Counseling, 419-427. http://dx.doi.org/10.5330/prsc.10.4.e43404402j07480u

[10] Craig, W.M. and Pepler, D.J. (2007) Understanding Bullying: From Research to Practice. Canadian Psychology, 48, 8693. http://dx.doi.org/10.1037/cp2007010

[11] Mitchell, D. (2008) What Really Works in Special and Inclusive Education. Using Evidence-Based Teaching Strategies. Book.

[12] Carter, B. and Spencer, V. (2006) The Fear Factor: Bulling and Students With Disabilities. International Journal of Special Education, 21, 11-23.

[13] Mclntyre, A. (2000) Constructing Meaning about Violence, School, and Community: Participatory Action Research with Urban Youth. The Urban Review, 32, 123-154. http://dx.doi.org/10.1023/A:1005181731698

[14] Ozer, E. and Weinstien, R. (2004) Urban Adolescents’ Exposure to Community Violence: The Role of Support, School Safety, and Social Constraints in a School-Based Sample of Boys and Girls. Journal of Clinical Child and Adolescent Psychology, 33, 463-476. http://dx.doi.org/10.1207/s15374424jccp3303_4

[15] Vaillancourt, T., McDougall, P., Hyrnel, S. and Sunderani, S. (2010) Respect of Fear? The Relationship between Power and Bulling Behavior. In: Jimerson, S.R., Swearer, S.M. and Espelage, D.L., Eds., Hand-Book of Bulling in Schools: An International Perspective, Routledge, New York, 211-222.

[16] Kaplan, I., Lewis, I. and Mumba, P. (2007) Picturing Global Educational Inclusion? Looking and Thinking across Students' Photographs from the UK, Zambia and Indonesia. Journal of Research in Special Educational Needs, 7, 23-35. http://dx.doi.org/10.1111/j.1471-3802.2007.00078.x

[17] Karni, N. and Reiter, S. (2014) Organizational Conditions and School Culture fostering Inclusive Education in Arab Schools in Israel. International Journal of Developmental Disabilities, 60, 205-214

[18] Karni, N., Reiter, S. and Bryen, D.N. (2011) Israeli Arab Teachers’ Attitudes Israeli Arab Teachers’ on Inclusion of Students with Disabilities. The British Journal of Developmental Disabilities, 57, 123-132. http://dx.doi.org/10.1179/096979511798967106

[19] Wedell, K. (2008) Confusion about Inclusion: Patching up or System Change? British Journal of Special Education, 35, 
128-143.

[20] Estell, D.B., Farmer, T.W., Irvin, M.J., Crowther, A., Akos, P. and Boudah, D.J. (2009) Students with Exceptionalities and the Peer Group Context of Bullying and Victimization in Late Elementary School. Journal of Child and Family Studies, 18,136-150. http://dx.doi.org/10.1007/s10826-008-9214-1.

[21] Hoover, J.H. and Stenhjem, P. (2003) Bulling and Teasing of Youth with Disabilities: Creating Positive School Environments for Effective Inclusion. National Center on Secondary Education and Transition Issue Brief, 2, 1-5. http://dx.doi.org/10.1002/pits.10052

[22] Harley, D.A., Nowak, M.T., Gassaway, J.L. and Savage, A.T. (2002) Lesbian, Gay, Bisexual, and Transgender College Students with Disabilities: A Look at Multiple Cultural Minorities. Psychology in the Schools, 39, 525-538.

[23] Horner-Johnson, W. and Drum, E.C. (2006) Prevalence of Maltreatment of People with Intellectual Disabilities: A Review of Recently Published Research, Mental Retardation and Developmental Disabilities. Research Reviews, 12, 57-69. http://dx.doi.org/10.1002/mrdd.20097

[24] Pachankis, J.E. (2007) The Psychological Implications of Concealing a Stigma: A Cognitive-Affective-Behavioral Model. Psychological Bulletin, 133, 328-345. http://dx.doi.org/10.1037/0033-2909.133.2.328 